\title{
ДЕЯКІ ДУМКИ З ПРИВОДУ МЕДИЧНОї РЕФОРМИ
}

\author{
ДВНЗ «Тернопільський державний медичний університет імені І.Я. Горбачевського МОЗ України», \\ м. Тернопіль, Україна
}

\begin{abstract}
Мета: проаналізувати і дати оцінку основним положенням медичної реформи стосовно демографрічної ситуації в Україні.

Матеріали і методи. Використані дані галузевої статистики щодо смертності населення, дані соціологічного опитування жінок Хмельницької області щодо відтворення людності.

Результати. На сьогодні демографічна ситуація в Україні характеризується таким негативним явищем, як значне перевищення смертності над народжуваністю. Яка причина цього катастрофрічного явища? Називають політичні, соціальні, економічні, медичні проблеми. Медична реформа на даний час не вирішує проблем депопуляції людності.

Висновок. У теперішній час медична реформа не надає належної уваги проблемам відтворення населення України.
\end{abstract}

КЛЮЧОВІ СЛОВА: смертність; народжуваність; відтворення; людність; реформа.

3 першого року незалежності в Україні почалось вимирання людності. Цей процес коливається в певних межах. Так, за останні 5 років незалежності людність України зменшилась на півмільйона осіб, а за три квартали цього року вимирання збільшилось, досягнувши 142 тис. осіб. Причини цього трагічного явища різні: регіональні, соціальні та медичні $[3,4,6,11,14,15]$. Особливо маловивченими $€$ регіональні та соціальні причини. В подальшому прогноз демографрічної ситуації в Україні не є втішним [3-5, 8].

Мета дослідження: проаналізувати і дати оцінку основним положенням медичної ресрорми стосовно демографічної ситуації в Україні.

Матеріали і методи. Використані дані галузевої статистики щодо смертності населення, дані соціологічного опитування жінок Хмельницької області щодо відтворення людності.

Результати дослідження та їх обговорення. За останні 5 років людність України зменшилась більше ніж на півмільйона осіб $[11,14,15]$. Темпи цього вимирання були такими (табл. 1):

Якщо згрупувати ці області за регіонами, то отримаємо наступну картину $[6,13,15]$ (табл. 2).

Як видно з таблиці 2, чим ближче Україна була до Московії і чим довше в ній перебувала, тим вищою була смертність [1]. І лише в західних областях, які найменше були в складі Московії, приріст людності позитивний. Дивовижне явище: в двох сусідніх областях Хмельницькій і Рівненській спостерігаємо протилежну картину здоров'я людей. У Хмельницькій області, яка за своїми природними даними значно багатша за Рівненську, людність вимирає, а в Рівненській області вона дає позитивний рівень.

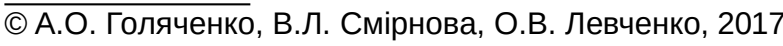

У чому тут справа? В тому, що порівняно з західними областями, в східних - пияцтво, поширеність абортів, число розлучень, які сильно впливають на смертність людей, в три-сім разів є вищою [13]. До речі, відразу відзначимо, що між рівнем медичного обслуговування і показником смертності зв'язок $€$ вельми слабким.

Наводимо дані опитування жінок щодо відтворення людності, яке ми провели в Хмельницькій області.

Число дітей в сім'ї у жінок 20-24 років була такою: мали 0,24 дитини в середньому на одну жінку, число бажаних дітей 2,01 на одну жінку. У жінок 25-30 років мали на одну жінку 0,47 дитини, число бажаних дітей 2,1. Таким чином, число бажаних дітей в двох основних дітородних групах відповідає мінімуму, що забезпечує приріст людності. Та реальність $€$ іншою. Як відповіла одна жінка: в такій державі, як Україна народжувати дітей немає сенсу. Основні причини, які стримують народження дітей наведено в таблиці 3.

Тепер про суто медичні фрактори реформи охорони здоров'я. Вони мають відносно невелике значення. Слід сказати, що за 26 років незалежності система охорони здоров'я прийшла в повний занепад. Основна причина цього - цілковите безгрошів'я. На її забезпечення виділялось трішки більше 2-3 \% валового внутрішнього продукту (ВВП). У 2017 р. частка витрат на охорону здоров'я складає 3,4 \% ВВП. Якщо з 2014 р. можна говорити про воєнні витрати, то яка причина того, що цей відсоток не збільшувався в попередні сприятливі роки [2, 7, 10]?

Зупинимось на основних моментах реформи. Відповідно до прийнятої в державі децентралізації кошти перерозподіляються з виділенням первинної ланки. Але за яким принципом будуть розподілені? Не за рахунок збільшення ролі первинної 
Таблиця 1. Вимирання людності в Україні

\begin{tabular}{|c|c|c|c|}
\hline Адміністративна територія & $\begin{array}{c}\text { Чисельність людності } \\
\text { України на 01.01.2016 р. }\end{array}$ & $\begin{array}{c}\text { Відношення процесів } \\
\text { народжуваності до } \\
\text { смертності } \\
\end{array}$ & $\begin{array}{c}\text { Відсоток щодо } \\
\text { попереднього } \\
\text { рівня } \\
\end{array}$ \\
\hline $\begin{array}{l}\text { Автономна Республіка Крим } \\
\text { та м. Севастополь }\end{array}$ & - & - & - \\
\hline Вінницька & 1596136 & $-38,0$ & $-2,4$ \\
\hline Волинська & 1042322 & $+7,9$ & $+0,8$ \\
\hline Дніпропетровська & 3241264 & $-92,0$ & $-2,8$ \\
\hline Донецька & 4252751 & $-167,3$ & $-3,9$ \\
\hline Житомирська & 1243913 & $-35,9$ & $-2,9$ \\
\hline Закарпатська & 1258818 & $+14,3$ & $+1,1$ \\
\hline Запорізька & 1745594 & $-54,9$ & $-3,1$ \\
\hline Івано-Франківська & 1380840 & $+3,8$ & $+0,3$ \\
\hline Київська & 1733835 & $+26,9$ & $+1,6$ \\
\hline Кіровоградська & 968970 & $-34,6$ & $-3,6$ \\
\hline Луганська & 2199608 & $-87,1$ & $-4,0$ \\
\hline Львівська & 2531743 & $+5,3$ & $+0,2$ \\
\hline Миколаївська & 1154022 & $-28,6$ & $-2,5$ \\
\hline Одеська & 2386015 & $+8,4$ & $+0,4$ \\
\hline Полтавська & 1431783 & $-48,1$ & $-3,4$ \\
\hline Рівненська & 1161618 & $+10,3$ & $+0,9$ \\
\hline Сумська & 1107751 & $-51,5$ & $-4,6$ \\
\hline Тернопільська & 1062516 & $-18,4$ & $-1,7$ \\
\hline Харківська & 2708608 & $-30,8$ & $-1,1$ \\
\hline Херсонська & 1058593 & $-28,2$ & $-2,7$ \\
\hline Хмельницька & 1290058 & $-33,7$ & $-2,6$ \\
\hline Черкаська & 1237171 & $-44,6$ & $-3,6$ \\
\hline Чернівецька & 908900 & $+7,7$ & $+0,8$ \\
\hline Чернігівська & 1039108 & $-50,6$ & $-4,9$ \\
\hline м. Київ & 2908249 & $+150,3$ & $+5,2$ \\
\hline Україна & 42650186 & -519000 & $-1,2$ \\
\hline
\end{tabular}

Таблиця 2. Людність України у 2011-2016 рр.

\begin{tabular}{|l|c|c|c|}
\hline \multicolumn{1}{|c|}{ Історичні регіони України } & $\begin{array}{c}\text { Людність } \\
\text { України }\end{array}$ & $\begin{array}{c}\text { Частка } \\
\text { померлих } \\
\text { людей }\end{array}$ & $\begin{array}{c}\text { Частка померлих } \\
\text { людей стосовно } \\
\text { всієї людності }\end{array}$ \\
\hline $\begin{array}{l}\text { Чернігівська, Сумська, Полтавська, Харківська обл. - } \\
\text { колишня Лівобережна Гетьманщина: майже 3,5 ст. у } \\
\text { складі Російської імперії - СРСР }\end{array}$ & 6287250 & -181000 & $-2,9$ \\
\hline $\begin{array}{l}\text { Вінницька, Житомирська, Хмельницька обл. - колишня } \\
\text { Правобережна Гетьманщина: майже 2 ст. у складі } \\
\text { Російської імперії - СРСР }\end{array}$ & 4130107 & -107602 & $-2,6$ \\
\hline $\begin{array}{l}\text { Дніпропетровська, Запорізька, Кіровоградська, Одеська, } \\
\text { Миколаївська, Херсонська, Донецька, Луганська обл. }- \\
\text { колишні Землі Війська Запорозького - менше 2 ст. у } \\
\text { складі Російської імперії - СРСР }\end{array}$ & 17006817 & -484980 & $-2,8$ \\
\hline $\begin{array}{l}\text { Тернопільська, Львівська, Івано-Франківська, } \\
\text { Чернівецька, Закарпатська обл. - колишня Галичина, } \\
\text { Буковина, Закарпаття: півстоліття в складі імперії СРСР, } \\
\text { Волинська, Рівненська }\end{array}$ & 9346757 & +121600 & $+1,3$ \\
\hline $\begin{array}{l}\text { Інші області } \\
\text { Київська, Черкаська, м. Київ }\end{array}$ & & & \\
\hline Загалом & 5879255 & +132600 & \\
\hline
\end{tabular}


Таблиця 3. Основні причини, які стримують народження дітей

\begin{tabular}{|l|c|c|c|c|}
\hline \multirow{2}{*}{ Основні причини } & \multicolumn{3}{|c|}{ Вік жінок } & \multirow{2}{*}{ Разом } \\
\cline { 2 - 5 } & $20-24$ & $25-29$ & 30 та старші & 354 \\
\hline Число відповідей & 89 & 119 & 146 & $5,4 \pm 1,2$ \\
\hline Складність виховання & $5,6 \pm 2,4$ & $3,5 \pm 2,1$ & $5,5 \pm 1,9$ & $1,7 \pm 0,7$ \\
\hline Нестача дошкільних закладів & $2,2 \pm 1,6$ & $1,8 \pm 1,2$ & $1,4 \pm 1,0$ & $7,4 \pm 1,4$ \\
\hline Погані житлові умови & $3,4 \pm 1,9$ & $8,8 \pm 2,7$ & $8,9 \pm 2,4$ & $22,9 \pm 2,2$ \\
\hline Великі грошові витрати & $25,8 \pm 4,6$ & $24,6 \pm 4,0$ & $19,9 \pm 3,3$ & $4,9 \pm 1,2$ \\
\hline Прагнення до профресійного росту & $10,1 \pm 3,2$ & $5,3 \pm 2,1$ & $1,4 \pm 1,0$ & $12,9 \pm 1,8$ \\
\hline Стан здоров'я & $5,6 \pm 2,4$ & $13,2 \pm 3,2$ & $17,1 \pm 3,8$ & $5,7 \pm 1,2$ \\
\hline Страх перед пологами & $9,0 \pm 3,0$ & $5,3 \pm 2,1$ & $4,1 \pm 1,6$ & $9,7 \pm 1,6$ \\
\hline Інші причини & $6,7 \pm 2,7$ & $7,9 \pm 2,5$ & $13,0 \pm 2,8$ & $29,4 \pm 2,4$ \\
\hline Не відповіли & $31,6 \pm 4,9$ & $28,7 \pm 4,2$ & $28,7 \pm 3,7$ & 2 \\
\hline
\end{tabular}

ланки, а за принципом «Трішкинакафтана» (в одного заберуть, другому дадуть). У 2018 р. середня виплата на первинній ланці становитиме близько 370 грн на одного пацієнта, в 2019 р. 450 грн. На 2000 пацієнтів це створить річний дохід у 740000 грн у 2018 р. та 900000 грн у 2019 р. У цей бюджет входять оренда, робота лікаря, фрельдшера та медсестри, прості витратні матеріали та часткове покриття аналізів. Ліки в цей бюджет не входять.

Тут порушується декілька положень класичної сімейної медицини.

По-перше, якщо залишається дільничний педіатр, то сімейний лікар насправді є дільничним терапевтом.

По-друге, кошти з бюджету сімейного лікаря мають перераховуватись на кошти лікарівспеціалістів, куди він направлятиме хворого. Сімейний лікар повинен надавати $90 \%$ усіх послуг, а не 50-60 \% як у нас. Ліки також має призначати сімейний лікар, але їх мають видавати хворим безоплатно [2]. У нас ліки в цей перелік не входять. Чи збільшаться можливості сімейного лікаря лікувати хворих в амбулаторіях? Судячи 3 його оснащення, ні. Виявляється, кожен хворий може обирати самостійно лікаря-срахівця, але за це він повинен платити сам. Тому збільшилася різниця між хворими, які йдуть до сімейного лікаря 3 усіма наслідками, і хворими, які здатні оплачувати спеціалізовану допомогу самостійно.

Маємо цивілізовані джерела суттєвого збільшення асигнувань на охорону здоров'я. Перше це відновлення державної монополії на виробництво і продаж алкоголю і тютюну. За радянських часів ця монополія давала третину бюджету, яка повністю йшла на охорону здоров'я, а також освіту і культуру. Тепер народ спивається більше, а кошти від цього йдуть на казкове збагачення невеликої кількості олігархів. Крім того, на відміну від державної монополії, більше половини приватної алкогольної продукції, як свідчать численні перевірки, $€$ неякісною або підробленою, що посилює ії згубний вплив на здоров'я людей. 10 тис. смертельних алкогольних отруєнь щороку, 16 тис. самогубств, 6 тис. убивств - у всіх цих страхітливих цифрах основним винуватцем $€$ алкоголь $[1,13]$. Про побічний згубний вплив на здоров'я людей як алкоголю, так і тютюну тут не говоримо.

Однією 3 дивовижних пертурбацій, яка трапилася у процесі утвердження ліберального ринку в Україні, є та, що затратна частина охорони здоров'я - лікувальна справа - залишилася в державній власності, а прибуткова - фрармацевтична справа - повністю передана в приватні руки. Фармацевтичний бізнес не поступається алкогольному за рівнем збагачення її власників $[9,12]$.

Були кволі спроби з боку МОЗ України і навіть Кабінету Міністрів обмежити «апетити» фрармацевтичних власників певними рамками, але вони провалились. Тут допущена принципова помилка: не адмініструванням, а відновленням державних аптек, як конкурентів приватним, слід впливати на ціноутворення фрармацевтичних засобів. Окрім зниження цін на медикаменти, це дасть вагомий приплив коштів у державну лікувальну справу. Замість цього фрармацевтична мафрія кинула 500000 грн на безкоштовну закупівлю ліків за деякими програмами. Це жалюгідна подачка з боку цієї мафії, бо для неї вона є мізерною за кількістю, а для пацієнтів створює додаткові труднощі.

Постає питання, що таке оплата за медичні послуги, адже послуг у нас десятки тисяч. Кожного року на 1000 мешканців орієнтовно 300 звертаються за швидкою медичною допомогою, 1700-1800 3 хворобами, приблизно 2003 яких орієнтовно госпіталізують. До речі, потрібно врахувати, що захворюваність людей невпинно зростає за останні 20 років - вдвічі [1]. В умовах, коли в країні відсутня загальноприйнята методика ціноутворення загальних медичних послуг, коли їх ціна залежить від рівня надання медичної допомоги та його оснащення, за обставин, коли все це змінюється, як можна визначити ціну медичних послуг? Адже вся система прагнула до спрощення цієї процедури, а не до її ускладнення. А кому надається право контролю за ціною медичних послуг? Виявляєть- 
ся - Національній службі здоров'я. Вся їх перевага полягає в найменших корупційних ризиках, оскільки вона, як центральний орган виконавчої влади, буде підконтрольна іншим контролюючим органам. Це дійсно новина, такого в нашій охороні здоров'я ще не було.
Висновок. У теперішній час медична рефрорма не надає належної уваги проблемам відтворення населення України.

Перспективи подальших досліджень полягають у виясненні причин явища депопуляції Української людності.

\section{Список літератури}

1. Голяченко О. М. Актуальні проблеми здоров'я української людності [Текст] : соціально-медичне дослідження : монографрія / О. М. Голяченко, А. О. Голяченко, А. Г. Шульгай. - Тернопіль : Лілея, 2012. - 116 с.

2. Горохов С. В. Порівняльний аналіз систем медичного страхування зарубіжних країн / С. В. Горохов, С. Д. Старинчук // Актуальні проблеми фрілософрії та соціології. - 2016. - № 9. - С. 24-28.

3. Демографрічні перспективи України до 2026 року. - К., 1999. - 55 с.

4. Демографрічні перспективи України: 2000-2075 роки / Е. М. Лібанова, О. В. Макарова, О. В. Позняк [та ін.] // Зайнятість та ринок праці : міжвідомчий наук. зб. - К. : РВПС України НАН України, 1999. - Вип. 11. - С. $126-141$.

5. Лібанова Е. М. Прогноз демографрічного розвитку України на період до 2050 року / Е. М. Лібанова // Світогляд. 2008. - № 3. - C. 48-51.

6. Медико-демографрічна ситуація та основні показники медичної допомоги населенню в регіональному аспекті. 2013 рік. - К. : МОЗ України, ДУ «УІСД МОЗ України», 2014. - 168 с.

7. Пашков В. М. Реформа охорони здоров'я від Уряду: аргументи за та проти / В. М. Пашков // Щотижневик АПТЕКА. 2015. - № 32 (1003). - С. 6-7.

8. Про демограсрічний прогноз розвитку України до 2050 року : постанова № 313 від 21.11.2007 р. Національної академії наук України (НАН).

9. Основні етапи нормування та впорядкування навчання й використання фрармацевтичної кадрової ресурсної бази / М. С. Пономаренко, О. С. Соловйов, Т. М. Краснянська [та ін.] // Актуальні питання фармацевтичної і медичної науки та практики. - 2016. - № 2 (21). - С. 110-117.

10. Деякі уроки реформи охорони здоров'я України / Г. О. Слабкий, В. М. Лехан, К. О. Надутий [та ін.] // Україна. Здоров'я нації. - 2014. - № 3. - С. 7-22.

11. Терець В. Природний рух населення й депопуляція в Україні на тлі європейської демограсрічної ситуації / В. Терець // Україна: аспекти праці. - 2010. - № 4. - С. 19-23.

12. Фармацевтична мафія проти реформ. Куди зникають ліки, закуплені державою? [Електронний ресурс]. Режим доступу : http://glavcom.ua/publications/farmacevtichna-mafiya-proti-reform-kudi-znikayut-liki-zakupleniderzhavoyu--356624.html

13. Щорічна доповідь про стан здоров'я населення, санітарно-епідеміологічну ситуацію та результати діяльності системи охорони здоров'я України. - К., 2016. - 452 с.

14. Чепелевська Л. А. Сучасні медико-демографрічні проблеми в Україні та шляхи їх подолання // Л. А. Чепелевська, О. П. Рудницький // Україна. Здоров'я нації. - 2015. - № 3 (35). - С. 39-43.

15. Чепелевська Л. А. Зміни в чисельності та статево-віковому складі населення України // Л. А. Чепелевська, О. П. Рудницький // Україна. Здоров'я нації. - 2014. - № 3 (31). - С. 33-40.

\section{References}

1. Holiachenko, O.M., Holiachenko, A.O., Shulhai, A.H. (2012). Aktualni problemy zdorovia ukrainskoi liudnosti: sotsialnomedychne doslidzhennia [Actual problems of the health of Ukrainian people: social and medical research]. Ternopil: Lileia [in Ukrainian].

2. Horokhov, S.V., \& Starynchuk, S.D. (2016). Porivnialnyi analiz system medychnoho strakhuvannia zarubizhnykh krain [Comparative analysis of medical insurance systems of foreign countries]. Aktualni problemy filosofii ta sotsiolohii - Actual Problems of Philosophy and Sociology, (9), 24-28.

3. Demohrafichni perspektyvy Ukrainy do 2026 roku [Demographic perspectives of Ukraine till 2026]. Kyiv [in Ukrainian].

4. Libanova, E.M., Makarova, O.V., \& Pozniak, O.V. (1999). Demohrafichni perspektyvy Ukrainy: 2000-2075 roky [Demographic perspectives of Ukraine: 2000-2075]. Zainiatist ta rynok pratsi: mizhvidomchyi nauk. zb. - Employment and Labor: Interdepartmental Scientific Collection. Kyiv: RVPS Ukrainy NAN Ukrainy [in Ukrainian].

5. Libanova, E.M. (2008). Prohnoz demohrafichnoho rozvytku Ukrainy na period do 2050 roku [The forecast of demographic development of Ukraine for the period up to 2050]. Svitohliad - Outlook, 3, 48-51 [in Ukrainian].

6. (2014). Medyko-demohrfichna sytuatsiia ta osnovni pokaznyky medychnoi dopomohy naselenniu $v$ rehionalnomu aspekti [The medical and demographic situation and the main indicators of medical care to the population in the regional aspect]. Kyiv: MOZ Ukrainy [in Ukrainian].

7. Pashkov, V.M. (2015). Reforma okhorony zdorovia vid Uriadu: arhumenty: za i proty [Healthcare reform from the Government: Arguments for and against]. Shchotyzhnevyk apteka - Weekly Drugstore, 32(1003), 6-7.

8. Pro demohrafichnyi prohnoz rozvytku Ukrainy do 2050 roku: postanova \# 313 vid 21.11. 2007 r. Natsionalnoi akademii nauk Ukrainy (NAN) [On the demographic forecast of Ukraine's development until 2050: Decree No. 313 of 21.11.2007 of the National Academy of Sciences of Ukraine (NAS)] [in Ukrainian].

9. Ponomarenko, M.S., Soloviov, O.S., \& Krasnianska, T.M. (2016). Osnovni etapy normuvannia ta vporiadkuvannia navchannia i vykorystannia farmatsevtychnoi kadrovoi resursnoi bazy [The main stages of the normalization and arranging 
of the training and use of the pharmaceutical personnel resource base]. Aktualni pytannia farmatsevtychnoi $i$ medychnoi nauky - Actual Issues of Pharmaceutical and Medical Science and Practice, 2 (21), 110-117 [in Ukrainian].

10. Slabkyi. H.O., Lekhan, V.M., \& Nadutyi, K.O. (2014). Deiaki uroky reformy okhorony zdorovia Ukrainy [Some lessons in health care reform in Ukraine]. Ukraina. Zdorovia Natsii - Ukraine. Health of Nation, (3), 7-22 [in Ukrainian].

11. Terets, V. (2010). Pryrodnyi rukh naselennia i depopiliatsiia v Ukraini na tli yevropeiskoi demohrafichnoi sytuatsii [Natural population movement and depopulation in Ukraine against the background of the European demographic situation]. Ukraina: aspekty pratsi - Ukraine: Aspects of Work, (4), 19-23 [in Ukrainian].

12. Farmatsevtychna mafia proty reform. Kudy znykaiut liky, zakupleni derzhavoiu? [Pharmaceutical mafia against reforms. Where do drugs disappear, bought by the state?]. [Electronic resource]. - Retrieved from: http://glavcom.ua/ publications/farmacevtichna-mafiya-proti-reform-kudi-znikayut-liki-zakupleni-derzhavoyu--356624.html [in Ukrainian].

13. (2016). Shchorichna dopovid pro stan zdorovia naselennia, sanitarno-epidemiolohichnu sytuatsiiu ta rezultaty diialnosti systemy okhorony zdorovia Ukrainy [Annual report on the health status of the population, the sanitary and epidemiological situation and the results of the health care system of Ukraine]. Kyiv [in Ukrainian].

14. Cheplevska, L.A. (2015). Suchasni medyko-demohrafichni problemy v Ukraini ta shliakhy yikh podolannia [Modern medical and demographic problems in Ukraine and ways to overcome them]. Ukraina. Zdorovia natsii - Ukraine. Health of Nation, 3 (35), 39-43 [in Ukrainian].

15. Cheplevska, L.A., \& Rudnytskyi, O.P. (2014). Zminy v chyselnosti ta statevo-vikovomu skladi naselennia Ukrainy [Changes in the number and sex-age composition of the population of Ukraine]. Ukraina. Zdorovia natsii - Ukraine. Health of Nation, 3 (31), 33-40 [in Ukrainian].

\section{НЕКОТОРЫЕ МЫСЛИ ПО ПОВОДУ МЕДИЦИНСКОЙ РЕФОРМЫ}

А.А. Голяченко, В.Л. Смирнова, О.В. Левченко

ГВУЗ «Тернопольский государственный медицинский университет имени И.Я. Горбачевского МЗ Украины», г. Тернополь, Украина

Цель: проанализировать и дать оценку основным положениям медицинской реформы относительно демограсрической ситуации в Украине.

Материалы и методы. Использованы данные отраслевой статистики смертности населения, данные социологического опроса женщин Хмельницкой области по вопросу воспроизводства населения.

Результаты. В настоящее время демографическая ситуация в Украине характеризуется таким негативным явлением, как значительное превышение смертности над рождаемостью. В чем причина этого катастрофического явления? Называются политические, социальные, экономические, медицинские проблемы. Медицинская реформа не решает проблем депопуляции населения.

Вывод. В настоящее время медицинская реформа не уделяет должного внимания проблемам воспроизводства населения Украины.

КЛЮЧЕВЫЕ СЛОВА: смертность; рождаемость; воспроизведение; население, реформа.

\section{SOME THOUGHTS ON THE MEDICAL REFORM}

A.O. Holyachenko, V.L. Smirnova, O.V. Levchenko

I. Horbachevsky Ternopil State Medical University

Purpose: to analyze and assess the main provisions of the medical reform regarding the demographic situation in Ukraine.

Materials and Methods. We used healthcare statistics data related to mortality of the population, data of the sociological study of women in Khmelnytskyi region regarding reproduction of population.

Results. Today, the demographic situation in Ukraine is characterized by such a negative phenomenon as significant excess of deaths over births. What is the reason for this catastrophic phenomenon? Political, social, economic, medical problems are mentioned. Medical reform does not solve the problems of depopulation.

Conclusion. Presently, the medical reform does not pay due attention to the problems of reproduction of the Ukrainian population.

KEY WORDS: mortality; fertility; reproduction; population; reform.

Рукопис надійшов до редакції 02.10.2017 p.

\section{Відомості про авторів:}

Голяченко Андрій Олександрович - доктор медичних наук, професор кафредри медичної реабілітації ДВНЗ «Тернопільський державний медичний університет імені І.Я. Горбачевського МОЗ України»; тел. +38(0352) 25-45-77. Смірнова Валентина Леонідівна - доцент кафедри соціальної медицини, організації та економіки охорони здоров'я з медичною статистикою ДВНЗ «Тернопільський державний медичний університет імені І.Я. Горбачевського МО3 України»; тел. +38(0352) 52-72-33.

Левченко Ольга Володимирівна - ДВНЗ «Тернопільський державний медичний університет імені І.Я. Горбачевського МО3 України»; тел. +38(0352) 52-72-33. 